\title{
Management of primary breast cancer
}

\author{
Arabella Melville, Alessandro Liberati, Roberto Grilli, Trevor Sheldon
}

This review is based on Effective Health Care, Vol 2 No 6

This paper describes research evidence on the management of primary breast cancer, defined as tumours of less than $5 \mathrm{~cm}$ diameter with no evidence of distant spread or metastases. It is based on Effective Health Care, Vol 2, No 6, which summarises analyses carried out for cancer guidance published by the United Kingdom Department of Health. ${ }^{12}$ The aim of the guidance was to identify characteristics of care which are associated with improved outcomes for patients.

\section{Background}

Breast cancer causes 13000 deaths a year in England and Wales. It is the leading cause of death in women aged 35 to 54 and the most common cause of cancer death among women. ${ }^{3}$ There are wide variations in management and in survival rates between areas and providers within the United Kingdom. ${ }^{411}$

\section{Diagnosis of primary breast cancer}

There is strong evidence for the value of the combination of clinical examination, mammography, and fine needle aspiration cytology - known as triple assessment - to diagnose cancer in women with breast lesions. A review of 15 follow up studies ${ }^{12}{ }^{27}$ showed that triple assessment is consistently more sensitive than any single test alone, capable of picking up $95 \%$ to $100 \%$ of cancers when at least one component is positive. When all three tests give the same result (whether positive or negative) the probability that the diagnosis is correct is about $99 \%$. Triple assessment can normally be carried out in a single clinic visit, thus minimising time to definitive diagnosis.

The accuracy of triple assessment depends on the skills of those who carry out the procedures and assess the results. The quality of fine needle aspiration cytology, in particular, is highly operator dependent and some clinicians are likely to need training in this area. ${ }^{131 \times 27}$

Triple assessment can release resources by reducing the proportion of women who need surgical biopsy and the inclusion of fine needle aspiration cytology has been shown to be cost effective. $1112142028-32$

\section{Management of primary breast cancer} SURGERY

For most women with early breast cancer, surgical options include breast conserving surgery (wide local excision or lumpectomy) and mastectomy. Randomised controlled trials have not shown any effect on life expectancy of type of surgery. ${ }^{33}$ Local rates of recurrence tend to be lower, the more tissue is removed. Against this potential advantage of more extensive surgery, however, the impact of disfigurement on the woman, her personal relations, and, in the case of surgical clearance of the axilla, iatrogenic arm problems, must be balanced. ${ }^{35}$

The option of breast conserving surgery (with adjuvant radiotherapy to reduce local recurrence) is suitable for women with relatively small and localised tumours. It is important that the margins of the tissue removed during surgery should be free from cancer, as local recurrence is more likely when cancer cells from tumour margins are left behind after surgery. ${ }^{36}$ Pathology reports which give sufficient detail to allow the rate of clear margins to be recorded are therefore essential for monitoring the quality of surgery.

Breast reconstruction after mastectomy removes dress problems associated with prostheses and may improve women's attitudes to their bodies. ${ }^{37+3}$ Retrospective studies suggest that women who have breast conserving surgery report a better body image and greater satisfaction than those who undergo mastectomy and immediate reconstruction, ${ }^{4+47}$ but the evidence for better general psychological and social adjustment after breast conserving surgery is equivocal. ${ }^{+850}$ Studies of women's reactions to different types of surgery are, however, generally of poor quality and the results may not be suitable for generalisation.

\section{RADIOTHERAPY}

Adjuvant radiotherapy after surgery reduces local recurrence rates to less than one third of those found in comparable women who have not had radiotherapy. ${ }^{33.451 .53}$ However, a systematic overview of randomised controlled trials involving a total of 17000 women showed no difference in overall survival; in those who had radiotherapy, a slight reduction in deaths from breast cancer was counterbalanced by an increase in deaths from cardiac related disease..$^{34}$ Comparison of mortalities in more recent trials with earlier studies indicates that the benefits in terms of lower mortality from breast cancer may have increased, whereas adverse effects seem to have been reduced, possibly due to a reduction in the doses used. ${ }^{5+}$

Although serious adverse effects seem to be uncommon, complications such as severe neuropathy, subcutaneous fibrosis, bone necrosis, and arm oedema can occur, particularly in women exposed to high dose regimens. ${ }^{5 \hbar}$ 
HORMONE THERAPY

Tamoxifen can improve survival and reduce recurrence rates in most groups of breast cancer patients. A systematic review conducted by the Early Breast Cancer Trialists' Collaborative Group, which included data from almost 30000 women in 40 randomised controlled trials, showed that tamoxifen treatment for one year or more was associated with highly significant absolute improvements in 10-year recurrence free survival. ${ }^{57}$ This benefit is greatest in women over 50 with axillary node involvement (table $1^{1}$ ).

Table 1 Effects of tamoxifen treatment; percentage of women remaining alive and free from recurrence after 10 years (all ages)

\begin{tabular}{lll}
\hline Axillary node status & Treated & Untreated \\
\hline Node positive & 41.9 & 33.1 \\
Node negative & 68.1 & 63.1 \\
\hline
\end{tabular}

Overall, the use of tamoxifen reduced the average annual odds of death by $17 \%$ (odds ratio (OR) $0.83 ; 95 \%$ confidence interval ( $95 \%$ CI) 0.79 to 0.87 ) and the average annual rate of recurrence by $25 \%$ (OR 0.75 ; $95 \%$ CI 0.72 to 0.78 ). There is no evidence that tamoxifen is effective for premenopausal women with oestrogen receptor negative tumours. ${ }^{58}$

The effects of treatment were considerably greater in trials lasting two to five years than in shorter term trials. However, on current evidence, the use of tamoxifen for more than five years does not seem to be justified. ${ }^{59}$ Tamoxifen treatment is associated with an increase in endometrial cancer, which may be counter balanced by a decreased incidence of cancer in the other breast.

The effects of ovarian ablation have been studied in over 3000 women. ${ }^{57}$ After 15 years, $53 \%$ of women treated at less than 50 years old remained alive and free from recurrence, compared with $42 \%$ of controls, but there seems to be no benefit for women over 50 . Ovarian ablation did not significantly affect non-breast cancer mortality over the period of follow up, but it causes sudden onset of menopause, for which women are unlikely to be offered hormone replacement therapy.

\section{CHEMOTHERAPY}

The effectiveness of polychemotherapy (usually CMF - cyclophosphamide, methotrexate, and 5-fluorouracil), was assessed in 18400 women enrolled in randomised controlled trials. After 10 years, $44 \%$ of treated women were alive and free from recurrence, compared with $35.6 \%$ of control women, with greater benefits among younger women. There was no apparent effect of chemotherapy on non-cancer related deaths. ${ }^{57}$ A recent meta-analysis based on data from 3920 patients in nine randomised controlled trials suggests that adding chemotherapy to tamoxifen in postmenopausal women does not significantly improve survival, and that the adverse effects of chemotherapy on quality of life may outweigh any potential benefit from the delay in recurrence. ${ }^{60}$

A review of five randomised controlled trials showed that acupuncture or acupressure is effective for reducing nausea and vomiting associated with chemotherapy. ${ }^{61}$

COST EFFECTIVENESS OF SYSTEMIC TREATMENT Analyses based on data from the United States consistently show that systemic treatment for early breast cancer can be highly cost effective, although a range of results have been reported. ${ }^{62-66}$ Estimates of the cost per quality adjusted life year (QALY) of treatment with tamoxifen range from $\$ 12000$ in node negative oestrogen receptor positive premenopausal women to $\$ 4000$ in node positive premenopausal women (1991 \$US).$^{6465}$ As the cost of tamoxifen in the United Kingdom is considerably less than in the United States, these figures are likely to underestimate its cost effectiveness in the United Kingdom.

The costs per QALY for adjuvant chemotherapy have been variously estimated at $\$ 1000-5000$ for premenopausal node positive women, ranging up to $\$ 36000-50000$ for post-menopausal node negative women (1991 and 1993 \$US). ${ }^{63-66}$

\section{Information and communication}

The most common complaints made by cancer patients are about poor communication and inadequate information. Some doctors have poor communication skills and a few behave in a way that may be perceived as insensitive, even callous. ${ }^{67}$

Because issues around breast cancer may produce intense emotional reactions, information has to be given in a clear and sensitive way. Focus groups of patients show that they want information in both verbal and written forms, about their cancer, treatment options, the likelihood of treatment success, and possible side effects. ${ }^{67}$ Patients who are given more complete information show greater satisfaction without any increase in anxiety. ${ }^{68}$

Communication difficulties are associated with anxiety, depression, anger, and confusion, ${ }^{69}$ particularly when the news of the cancer diagnosis is given for the first time, after which some patients may fail to take in information. ${ }^{67}$ Studies of consultations suggest that cancer patients and their doctors may disagree about the adequacy of information given. ${ }^{70-77}$ Patients often think that they are not given sufficient information, whereas doctors tend to overestimate the amount of information that they give. ${ }^{6878}$ Some doctors are not convinced of the value of giving full information to patients ${ }^{75-77}$ and some perform the difficult task of telling bad news in a routine manner. ${ }^{77}$

Patients are likely to get more complete information when it is given in a structured way. They find audiotapes of their consultation and information booklets about treatment helpful. ${ }^{79-85}$ The fact that they want to be properly informed does not, however, mean that they necessarily want to be responsible for the 
final treatment decisions. ${ }^{86}$ Women vary in the degree to which they want to take an active role in decision making. ${ }^{69-94}$

Table 2 shows the studies that explore the effects of choice between mastectomy and breast conserving surgery. Benefits may include reduced depression and anxiety ${ }^{95}$ and a higher level of life satisfaction. ${ }^{97}$ One study suggested that offering a choice could cause distress ${ }^{98}$ and other studies reported that $15 \%$ $37 \%$ of women found the process of making a choice problematic..$^{95-97}$

Table 2 Effects of choice between breast conserving surgery (BCS) and mastectomy (MST)

\begin{tabular}{|c|c|c|c|c|c|c|c|}
\hline $\begin{array}{l}\text { Author, year, } \\
\text { country }\end{array}$ & Aim of study & Patient groups & $\begin{array}{l}\% \text { Able } \\
\text { to choose }\end{array}$ & $\begin{array}{l}\% \\
\text { Choosing } \\
\text { BCS }\end{array}$ & Outcomes assessed & Results & Grade \\
\hline $\begin{array}{l}\text { Street et al } \\
1995^{105} \\
\text { USA }\end{array}$ & $\begin{array}{l}\text { To assess the effects of } \\
\text { two methods of } \\
\text { preconsultation } \\
\text { education }\end{array}$ & $\begin{array}{l}\text { Interactive video disk } \\
(\mathrm{n}=30) \\
\text { Information brochure } \\
(\mathrm{n}=30)\end{array}$ & 100 & 76 & $\begin{array}{l}\text { Active role in } \\
\text { consultation, type of } \\
\text { surgery chosen }\end{array}$ & $\begin{array}{l}\text { Preconsultation education well received } \\
\text { and thought to enhance involvement in } \\
\text { decision making, no difference between } \\
\text { the two techniques }\end{array}$ & I \\
\hline $\begin{array}{l}\text { Fallofield et al } \\
1994^{95} \mathrm{UK}\end{array}$ & $\begin{array}{l}\text { To determine the impact } \\
\text { of offering women a } \\
\text { choice about surgery in } \\
\text { early breast cancer }\end{array}$ & $\begin{array}{l}\text { Patients treated by: } \\
\text { (a) surgeons favouring } \\
\text { MST ( } n=30) \\
\text { (b) surgeons favouring } \\
\text { BCS }(n=121) \\
\text { (c) surgeons offering } \\
\text { choice }(n=118)\end{array}$ & - & - & $\begin{array}{l}\text { Anxiety and } \\
\text { depression at } 3,6, \\
12 \text {, and } 36 \text { months, } \\
\text { fear of recurrence, } \\
\text { attitude to disease } \\
\text { and treatment, type } \\
\text { of surgery chosen }\end{array}$ & $\begin{array}{l}\text { At } 3 \text { years between } 1 / 4 \text { and } 1 / 5 \text { patients } \\
\text { were anxious and depressed irrespective } \\
\text { of their role in treatment decision, } \\
\text { women treated by surgeons who offered } \\
\text { choice were less depressed than those } \\
\text { treated by surgeons favouring MST, } \\
42 \% \text { of patients were pleased they had } \\
\text { been allowed to choose; } 13 \% \text { unable to } \\
\text { decide; } 37 \% \text { said they had difficulties }\end{array}$ & IIA \\
\hline $\begin{array}{l}\text { Levy et al } \\
1989^{98} \\
\text { USA }\end{array}$ & $\begin{array}{l}\text { To assess emotional } \\
\text { distress sequelae as a } \\
\text { function of choice of } \\
\text { surgical treatment }\end{array}$ & $\begin{array}{l}\text { A group of patients } \\
\text { participating in a study } \\
\text { examining behavioural } \\
\text { predictors of recurrence } \\
\text { of disease }(n=98)\end{array}$ & - & 70 & $\begin{array}{l}\text { Emotional distress, } \\
\text { social support, } \\
\text { anxiety and } \\
\text { depression, } \\
\text { functional status }\end{array}$ & $\begin{array}{l}\text { When choices played a major part, BCS } \\
\text { patients were psychologically worse off } \\
\text { at } 3 \text { months follow up, the assumption } \\
\text { that women are psychologically better } \\
\text { off opting for BCS should be } \\
\text { re-examined }\end{array}$ & IIA \\
\hline $\begin{array}{l}\text { Pozo et al } \\
1992^{100} \\
\text { USA }\end{array}$ & $\begin{array}{l}\text { To assess, at one year } \\
\text { follow up, the } \\
\text { psychosocial impact of } \\
\text { offering choice between } \\
\text { BCS and MST }\end{array}$ & $\begin{array}{l}\text { A group of private } \\
\text { patients seen at a } \\
\text { tertiary care institution } \\
\text { in the process of } \\
\text { deciding between BCS } \\
\text { and MST }(n=63)\end{array}$ & 61 & 41 & $\begin{array}{l}\text { Emotional distress, } \\
\text { overall quality of life, } \\
\text { life satisfaction, } \\
\text { marital satisfaction, } \\
\text { perceived social } \\
\text { support, type of } \\
\text { surgery chosen }\end{array}$ & $\begin{array}{l}\text { Choice of surgical procedure predicted } \\
\text { higher levels of life satisfaction at } 3 \\
\text { months, BCS patients reported higher } \\
\text { sexual adjustment at } 6-12 \text { months after } \\
\text { surgery }\end{array}$ & IIA \\
\hline $\begin{array}{l}\text { Cotton et al } \\
1991^{103} \mathrm{UK}\end{array}$ & $\begin{array}{l}\text { To assess how often } \\
\text { patients opt for BCS } \\
\text { when they are offered } \\
\text { the choice }\end{array}$ & $\begin{array}{l}\text { Group not eligible for } \\
\text { BCS ( } n=72) \\
\text { Group not eligible for } \\
\text { BCS }(n=91)\end{array}$ & 100 & - & $\begin{array}{l}\text { Type of surgery } \\
\text { chosen }\end{array}$ & $\begin{array}{l}\text { Even when offered a choice, many } \\
\text { women }(50 \%) \text { opt for more radical } \\
\text { procedures, younger women more likely } \\
\text { to prefer BCS }\end{array}$ & IIB \\
\hline $\begin{array}{l}\text { Hughes } \\
1993^{99} \\
\text { USA }\end{array}$ & $\begin{array}{l}\text { To assess: (a) the } \\
\text { relation between amount } \\
\text { and type of information } \\
\text { regarding treatment and } \\
\text { type of surgery (b) the } \\
\text { relation between a } \\
\text { patient's choice of } \\
\text { treatment and her ability } \\
\text { to recall salient } \\
\text { information }\end{array}$ & $\begin{array}{l}\text { A group of patients in } \\
\text { the process of deciding } \\
\text { between BCS and MST } \\
(n=71)\end{array}$ & 100 & 65 & $\begin{array}{l}\text { Amount and nature } \\
\text { of information, recall } \\
\text { of specific pieces of } \\
\text { information, overall } \\
\text { quality of life and } \\
\text { functional status }\end{array}$ & $\begin{array}{l}\text { Treatment choice was unrelated to the } \\
\text { amount of information conveyed to the } \\
\text { patients at their clinic visit, quality of } \\
\text { life and functional status did not differ } \\
\text { between those opting for BCS or MST }\end{array}$ & IIB \\
\hline $\begin{array}{l}\text { Leinster et al } \\
\qquad 1989^{101} \mathrm{UK}\end{array}$ & $\begin{array}{l}\text { To assess the usefulness } \\
\text { of an informal decision } \\
\text { analysis tool to help } \\
\text { women make the best } \\
\text { subjective decision }\end{array}$ & $\begin{array}{l}\text { Women seen at surgical } \\
\text { department, University } \\
\text { of Liverpool }(n=43)\end{array}$ & 42 & 48 & $\begin{array}{l}\text { Satisfaction with the } \\
\text { choice made, type of } \\
\text { surgery chosen, } \\
\text { occurrence of } \\
\text { depression and } \\
\text { anxiety }\end{array}$ & $\begin{array}{l}\text { No difference in psychological } \\
\text { adaptation between groups identified by } \\
\text { treatment chosen, patients thought that } \\
\text { they had been able to choose the } \\
\text { treatment they wanted }\end{array}$ & IIB \\
\hline $\begin{array}{l}\text { Morris and } \\
\text { Royle } \\
1988^{96} \mathrm{UK}\end{array}$ & $\begin{array}{l}\text { To prospectively record } \\
\text { psychological variables } \\
\text { in patients (and their } \\
\text { husbands) to ascertain } \\
\text { the effects on } \\
\text { adjustment of being } \\
\text { offered a choice }\end{array}$ & $\begin{array}{l}\text { Group with central } \\
\text { lesion: no choice }(n=10)\end{array}$ & 100 & 65 & $\begin{array}{l}\text { Anxiety and } \\
\text { depression, social } \\
\text { and working } \\
\text { activities, marital } \\
\text { relations, type of } \\
\text { surgery chosen }\end{array}$ & $\begin{array}{l}\text { At } 6 \text { months follow up patients offered } \\
\text { a choice had lower (not significant) } \\
\text { levels of anxiety and depression, and } \\
\text { reported better adjustment with respect } \\
\text { to work and attitudes toward the future }\end{array}$ & IIB \\
\hline $\begin{array}{l}\text { Wilson et al } \\
1988^{97} \mathrm{UK}\end{array}$ & $\begin{array}{l}\text { To determine whether, } \\
\text { given the choice, } \\
\text { patients would prefer } \\
\text { BCS ot MST }\end{array}$ & $\begin{array}{l}\text { Patients seen at } \\
\text { Newcastle General } \\
\text { Hospital 1979-87 } \\
(n=153)\end{array}$ & 100 & 35 & $\begin{array}{l}\text { Type of surgery } \\
\text { chosen, difficulties } \\
\text { experienced in } \\
\text { making the choice } \\
\text { (subgroup of } 28 \\
\text { patients) }\end{array}$ & $\begin{array}{l}\text { Common reasons for choosing } \\
\text { mastectomy included employment, } \\
\text { hope of more rapid recovery, fear of } \\
\text { radiotherapy, of } 28(28 \%) \text { patients } \\
\text { interviewed } 2 \text { years after surgery, } 24 \\
\text { said it was not difficult to choose, } 4 \text { had } \\
\text { problems with the choice }\end{array}$ & IIC \\
\hline $\begin{array}{l}\text { Wolberg et al } \\
1987^{102} \\
\text { USA }\end{array}$ & $\begin{array}{l}\text { To find the proportion } \\
\text { of patients who, given } \\
\text { the choice, opt for BCS, } \\
\text { and to assess the } \\
\text { psychological factors } \\
\text { that predict preference }\end{array}$ & $\begin{array}{l}\text { A series of consecutive } \\
\text { patients seen at the } \\
\text { Department of Surgery, } \\
\text { University of Wisconsin } \\
(n=206)\end{array}$ & 53 & 49 & $\begin{array}{l}\text { Psychological } \\
\text { correlates of choice, } \\
\text { type of surgery } \\
\text { chosen }\end{array}$ & $\begin{array}{l}\text { No demographic variable was } \\
\text { associated with choice, women choosing } \\
\text { BCS valued their physical appearance } \\
\text { more highly and were less anxious and } \\
\text { depressed }\end{array}$ & IIA \\
\hline $\begin{array}{l}\text { Ward et al } \\
1989^{104} \\
\text { USA }\end{array}$ & $\begin{array}{l}\text { To assess: (a) which } \\
\text { factors patients consider } \\
\text { when deciding between } \\
\text { MST and BCS (b) to } \\
\text { what extent patients } \\
\text { participate in treatment } \\
\text { decision (c) what } \\
\text { sources of information } \\
\text { they use }\end{array}$ & $\begin{array}{l}\text { A group who meet the } \\
\text { surgical criteria for } \\
\text { choice between MST } \\
\text { and BCS }(n=22)\end{array}$ & 100 & 50 & $\begin{array}{l}\text { Factors women value } \\
\text { when deciding } \\
\text { between MST and } \\
\text { BCS, perceived } \\
\text { participation, sources } \\
\text { of information }\end{array}$ & $\begin{array}{l}\text { Desire for body integrity and fear of } \\
\text { radiotherapy were the two main reasons } \\
\text { for preferring BCS and MST, } \\
\text { respectively, } 91 \% \text { said that they had } \\
\text { participated as much as they desired, } \\
50 \% \text { said they want the decision to be } \\
\text { fully their own, the remaining } 50 \% \text { said } \\
\text { they want to share it mostly with } \\
\text { doctors }\end{array}$ & IIIC \\
\hline
\end{tabular}




\section{Psychosocial support}

Cancer patients need general emotional support and some also require practical help for example, with caring for children or other dependants or holding down a job. Doctors and nurses often fail to recognise patients' practical and emotional needs. ${ }^{106-110}$

PSYCHOSOCIAL AND PSYCHOTHERAPEUTIC INTERVENTIONS

Thirteen studies which assessed the effects of a range of interventions were identified ${ }^{111-125}$ (table 3) and also two critical reviews of the literature. ${ }^{126127}$ These studies show that psychotherapeutic, counselling and educational interventions can improve quality of life and may possibly improve immune function and increase life expectancy in cancer patients. Interventions involved group or individual treatment, and usually included exploration of anxieties, expression of feelings about illness, and related problems. Many attempted to replace undesirable ways of thinking or behaving with alternatives.

Cognitive or behavioural interventions can also be effective for helping patients to cope with symptoms and side effects of cancer treatment. ${ }^{128-149}$

Therapeutic interventions were given by a range of people, including nurses, psychologists, and psychiatrists. In general, interventions that focused on past problems, as in the psychoanalytical model, were not found to be effective, whereas those which dealt with the patient's current problems were more likely to be helpful.

A more definitive statement about the impact of psychosocial interventions is not possible because of the quality of the studies, which are often small and poorly controlled. The multiplicity of types of intervention and outcomes used make comparisons between studies difficult. However, when considered in conjunction with evidence that informal social support from partners, friends, and relatives is associated with better outcomes, ${ }^{150-158}$ this research highlights the importance of psychosocial issues for breast cancer patients.

\section{Follow up after primary treatment}

Routine hospital follow up of patients who have completed primary treatment (involving some combination of hospital physician visits, bone scans, sonograms, chest radiograms, and laboratory tests) is currently standard practice. ${ }^{159}$

The effectiveness of different follow up strategies was assessed in two well conducted Italian randomised controlled trials ${ }^{160161}$ and a British randomised controlled trial comparing follow ups based in general practice with those based in hospital. ${ }^{162}$ In the Italian studies, no difference was found in five year survival (OR $1.03 ; 95 \%$ CI 0.82 to 1.30 ) or health related quality of life between patients allocated to intensive surveillance or to a control regimen in which patients were seen as often by doctors, but tests were performed only when patients reported problems. All women received a yearly mammogram.
The British randomised controlled trial found that patients followed up by their general practitioners experience the same duration and quality of life as those cared for by specialist clinics, and that follow up by the general practitioner is acceptable to both patients and practitioners. Most recurrences are symptomatic and are usually detected first by patients themselves. ${ }^{162}$

Economic evaluations of different strategies in the Italian healthcare system found that the cost of intensive follow up was three to five times greater than for minimalist follow up. ${ }^{163}$ Studies in the United States also suggest that considerable savings could be achieved by less intensive follow up. ${ }^{66164165}$ In England and Wales, where a smaller proportion of specialists carry out intensive testing, ${ }^{159}$ the savings may be less, but the reduction in the number of specialist outpatient visits could allow the time saved to be used for activities which are more likely to benefit patients.

Although routine follow up may not be beneficial, each woman should have a contact number for her breast care nurse and be able to access care rapidly when required. This has been shown in a study in Scotland to lead to better quality of life and lower levels of psychological and physical morbidity than either routine care or support from a local voluntary agency. ${ }^{112}$

\section{The breast care team}

SPECIALISATION

The complexity and multifaceted nature of management of breast cancer requires the involvement of a range of different types of specialist, working together in a co-ordinated team. Specialisation of team members has been defined in terms of qualifications, experience, and time devoted to the management of breast cancer. ${ }^{1}$ Studies in this area are, in general, retrospective and observational, and thus susceptible to bias. Nevertheless, considered together, they point to the likely improvement in effectiveness associated with specialist treatment by multidisciplinary teams. ${ }^{79}$ 166-183

There is fairly strong evidence that specialist providers are more likely to provide good quality and up to date surgical care..$^{79^{166-174}}$ However, many of these studies used process measures of dubious validity to indicate quality of care - such as the probability of breast conserving surgery. Specialisation was usually defined in terms of the teaching status or size of the hospital, not the composition of the breast care team.

An observational study in Scotland found that women treated by surgeons regarded as breast cancer specialists had an $8 \%$ better chance of survival at 10 years. After adjustment for age, socioeconomic status, and cancer stage, the reduction in risk of death was $16 \%$ (95\% CI $6 \%$ to $25 \%$ ).

A meta-analysis of this and other observational studies shows that specialisation (however defined) is consistently associated with improved survival in breast cancer patients. ${ }^{2}$ Overall, the reduction in five year mortality associated with specialist care was 
Table 3 Effectiveness of psychosocial or psychotherapeutic counselling or support

\begin{tabular}{|c|c|c|c|c|c|c|}
\hline \multirow[b]{2}{*}{ Author, year } & \multirow{2}{*}{$\begin{array}{l}\text { Patients } \\
n(\% \\
\text { with } \\
\text { breast } \\
\text { cancer) }\end{array}$} & \multicolumn{2}{|l|}{ Follow up } & \multirow[b]{2}{*}{$\begin{array}{l}\text { Content of interventions, type of provider, and } \\
\text { patient }\end{array}$} & \multirow[b]{2}{*}{ Results } & \multirow[b]{2}{*}{ Grade } \\
\hline & & Duration & $\begin{array}{l}\text { Lost to } \\
\text { follow } \\
\text { up }\end{array}$ & & & \\
\hline $\begin{array}{l}\text { Speigel et al } 1989^{111} \text {, } \\
1983^{115}, 1981^{116}\end{array}$ & $\begin{array}{l}58 \\
(100)\end{array}$ & $\begin{array}{l}12 \\
\text { months }\end{array}$ & 48 & $\begin{array}{l}\text { Psychiatrist, social worker, and an ex-patient led } \\
90 \text { minute sessions of group psychotherapy, once } \\
\text { a week for one year. Control group received usual } \\
\text { care. Metastatic breast cancer patients }\end{array}$ & $\begin{array}{l}10 \text { years: the intervention increased survival by } \\
18 \text { months. The effect was apparent form the } \\
8 \text { th month of treatment. } 12 \text { months: the } \\
\text { intervention group used less psychotropic drugs } \\
\text { and analgesics. Anxiety and depression } \\
\text { decreased, and other psychological measures } \\
\text { improved. Mood improvement was directly } \\
\text { correlated with reduction in duration of pain. } \\
\text { Thought that control of pain was improved }\end{array}$ & IB \\
\hline McArdle et al $1996^{112}$ & $\begin{array}{l}272 \\
(100)\end{array}$ & $1 \mathrm{y}$ & 3 & $\begin{array}{l}\text { Psychological and informative support was } \\
\text { given for one year to patients by a specialised } \\
\text { nurse (since before surgery), or voluntary } \\
\text { organisation (after surgery) or nurse }+ \\
\text { voluntary organisation, or staff with routine } \\
\text { approach and booklet }\end{array}$ & $\begin{array}{l}\text { The group supported by the nurse had } \\
\text { significantly better general health, less insomnia, } \\
\text { psychological symptoms, social dysfunction, } \\
\text { and somatic symptoms }\end{array}$ & IB \\
\hline Burton et al $1995^{113}$ & $\begin{array}{l}215 \\
(100)\end{array}$ & $1 \mathrm{y}$ & 15 & $\begin{array}{l}\text { Preoperative interview, preoperative interview + } \\
\text { psychotherapeutic intervention }(30 \mathrm{~min}), \\
\text { preoperative interview }+ \text { talk }(30 \mathrm{~min}) \text {. } \\
\text { Consultant surgeon trained in client centred } \\
\text { counselling. Women awaiting mastectomy }\end{array}$ & $\begin{array}{l}\text { Multivariate analysis showed that the } \\
\text { experimental intervention was a significant } \\
\text { predictor of improvement of psychological } \\
\text { symptoms and coping strategies, together with } \\
\text { stressful life events, age, marital status, and } \\
\text { social support }\end{array}$ & IB \\
\hline Edgar et al $1992^{114}$ & $\begin{array}{l}205 \\
(48)\end{array}$ & $1 \mathrm{y}$ & 35 & $\begin{array}{l}\text { Relaxation training and problem solving } \\
\text { techniques in two different phases of illness } \\
\text { (just after diagnosis and some months later). } \\
\text { Nurse, various cancer type patients at different } \\
\text { moments of the disease }\end{array}$ & $\begin{array}{l}\text { At } 8 \text { months follow up differences between } \\
\text { groups were significant for depression, anxiety, } \\
\text { and control. The group with the nurse's } \\
\text { intervention had more benefit. Physical health } \\
\text { was the most significant covariate }\end{array}$ & IB \\
\hline Watson et al $1988^{117}$ & $\begin{array}{l}20 \\
(100)\end{array}$ & $1 \mathrm{y}$ & 30 & $\begin{array}{l}\text { Psychosocial support and information group } \\
\text { held by a specialist nurse for one year. Specialist } \\
\text { nurse, not further specified. Breast cancer } \\
\text { patients just after diagnosis }\end{array}$ & $\begin{array}{l}\text { At } 3 \text { months follow up the experimental group } \\
\text { showed less depression, better adjustment to } \\
\text { disease, and more working activity; but at } 1 \text { year } \\
\text { follow up the difference disappeared. No } \\
\text { difference for anxiety }\end{array}$ & IB \\
\hline Mock et al $1994^{118}$ & $\begin{array}{l}14 \\
(100)\end{array}$ & 1 month & 0 & $\begin{array}{l}\text { Physical exercise ( } 10-45 \text { minutes } 4-5 \text { times a } \\
\text { week) and psychological support group ( } 90 \\
\text { minutes every two weeks). Oncology clinical } \\
\text { specialist nurse specifically trained. Patients in } \\
\text { chemotherapy (stage I and II). Breast cancer } \\
\text { patients }\end{array}$ & $\begin{array}{l}\text { Adjustment to disease was worse in the control } \\
\text { group. Emotional distress increased in the } \\
\text { control group and decreased in treated patients }\end{array}$ & IB \\
\hline $\begin{array}{l}\text { Grossarth-Maticek and } \\
\text { Eysenck } 1989^{119}\end{array}$ & $\begin{array}{l}100 \\
(100)\end{array}$ & $3 y$ & 0 & $\begin{array}{l}\text { Patients randomised to psychotherapy } \\
\text { (behavioural, creative, depth), only } \\
\text { chemotherapy, both chemotherapy and } \\
\text { psychotherapy, or none. Provider not specified. } \\
\text { Late stage patients in chemotherapy }\end{array}$ & $\begin{array}{l}\text { Number of lymphocytes and survival increased } \\
\text { in the } 3 \text { experimental groups. Survival was } 14.9 \\
\text { months in the psychotherapy group, } 14.1 \text { in } \\
\text { chemotherapy, } 22.4 \text { in the group with both } \\
\text { treatments }\end{array}$ & IC \\
\hline Telch and Telch $1986^{120}$ & $41(40)$ & 6 weeks & 0 & $\begin{array}{l}\text { Six } 90 \text { minute sessions once a week of } \\
\text { behavioural strategies or psychological support } \\
\text { group. Social worker, psychologist. Various } \\
\text { cancer patients }\end{array}$ & $\begin{array}{l}\text { Behavioural strategy group improved } \\
\text { psychological adjustment to illness }\end{array}$ & IC \\
\hline Gordon et al $1980^{122}$ & $\begin{array}{l}308 \\
(32)\end{array}$ & $\begin{array}{l}12 \\
\text { months }\end{array}$ & 36 & $\begin{array}{l}\text { Six month group with educational and } \\
\text { emotional counselling and "environmental } \\
\text { manipulation". Psychologist, social worker, and } \\
\text { nurse, not further specified. Cancer patients, } \\
\text { any stage }\end{array}$ & $\begin{array}{l}\text { The experimental group experienced a faster } \\
\text { decrease of anxiety, depression, and hostility, } \\
\text { improved general quality of life. Return to work } \\
\text { was also slightly more frequent in treated } \\
\text { patients }\end{array}$ & IIB \\
\hline Maguire et al $1983^{121}$ & $\begin{array}{l}152 \\
(100)\end{array}$ & $\begin{array}{l}18 \\
\text { months }\end{array}$ & 0 & $\begin{array}{l}\text { Physical rehabilitation of the arm, expression of } \\
\text { feelings about the scar and body image, } \\
\text { encouragement to return to work. Specialist } \\
\text { nurse, not further specified. Radical } \\
\text { mastectomy patients }\end{array}$ & $\begin{array}{l}\text { The specific intervention was not effective. } \\
\text { However, } 89 \% \text { of women in experimental group } \\
\text { with psychiatric problems were recognised by } \\
\text { the specialist nurse, versus } 22 \% \text { among } \\
\text { controls. } 3 \% \text { in the intervention group had } \\
\text { moderately severe anxiety and } 4 \% \text { depression, } \\
\text { versus } 21 \% \text { and } 20 \% \text { in the control group at } \\
12-18 \text { months. Adjustment to illness and } \\
\text { working activity improved. No differences in the } \\
\text { functioning of arm, but pain lower in } \\
\text { experimental group }\end{array}$ & IIC \\
\hline Houts et al $1986^{123}$ & $32(?)$ & $\begin{array}{l}3 \\
\text { months }\end{array}$ & 20 & $\begin{array}{l}\text { Routine supporting intervention reinforced by } 3 \\
\text { phone calls, before and after the surgical } \\
\text { intervention, aiming at improving the coping } \\
\text { strategies of the patients. Social worker who had } \\
\text { had breast cancer. Newly diagnosed cancer } \\
\text { patients }\end{array}$ & $\begin{array}{l}\text { No effect was found in the group receiving the } \\
\text { enriched intervention, compared with routine } \\
\text { care }\end{array}$ & IIC \\
\hline Youssef $1984^{124}$ & $\begin{array}{l}18 \\
(100)\end{array}$ & $\begin{array}{l}2 \\
\text { months }\end{array}$ & 0 & $\begin{array}{l}18 \text { sessions of group therapy lasting } 1 \text { hour } \\
\text { every other day held for } 6 \text { weeks by a } \\
\text { psychiatric nurse. Intervention based on crisis } \\
\text { and self concept theory. Psychiatric nurse, not } \\
\text { further specified, with the investigator. Breast } \\
\text { cancer patients admitted to hospital for } \\
\text { treatment }\end{array}$ & $\begin{array}{l}\text { The differences between the two groups did not } \\
\text { reach significance. Some improvement in self } \\
\text { esteem and depression in the intervention } \\
\text { group }\end{array}$ & IIC \\
\hline $\begin{array}{l}\text { Morgenstern et al } \\
1984^{125}\end{array}$ & $\begin{array}{l}120 \\
(100)\end{array}$ & $6 y$ & 45 & $\begin{array}{l}\text { Psychotherapy groups were held for } 90 \text { minutes } \\
\text { once a week. Provider not specified. }\end{array}$ & $\begin{array}{l}\text { After adjustment for interval between diagnosis } \\
\text { and entrance to the programme, no significant } \\
\text { effect was found on survival at } 90 \text { months, but } \\
\text { survival was longer in the treated group until } 70 \\
\text { months }\end{array}$ & IIIB \\
\hline
\end{tabular}


$18 \%$ (95\% CI $12 \%$ to $23 \%$ ). This estimate should, however, be treated with caution because it is derived from studies which are susceptible to bias, due, for example, to inadequate adjustment for differences in case mix.

Specialist nurses can also contribute to improved outcomes for patients, in particular by reducing anxiety and depression and helping patients to participate in choices about treatment. $^{7074117121122144}{ }^{184-200}$ Oncology nurses can improve the use of chemotherapy resources, especially when they share some responsibilities with doctors. ${ }^{201} 202$

\section{VOLUME OF PATIENT THROUGHPUT}

Very low patient throughput tends to be associated with poorer management and long term outcomes, but the precise threshold below which this effect occurs is unclear. Improved outcomes with higher numbers may be a consequence of better surgical ${ }^{171}{ }^{178}{ }^{183}$ and non-surgical ${ }^{611}$ care, and may also be linked with more accurate diagnoses. ${ }^{180} 181$

In a Yorkshire study, women managed by surgeons who treated more than 30 new breast cancer patients a year were found to have lower five year mortalities. ${ }^{6}$ However, there is no evidence that the association between higher patient throughput and better quality of care holds for larger volumes. For example, a study comparing hospitals with 100 and 200 patients a year showed no difference in outcomes. ${ }^{178}$

\section{Conclusions}

There seems to be scope for improving outcomes in breast cancer through changes in the organisation of services. This would involve the establishment of specialist breast care teams and one stop diagnostic clinics.

The breast care team should work within written guidelines promoting the use of treatments, the effectiveness of which has been shown by research. ${ }^{203}$ The team should ensure that good verbal and written information is given to patients and key personnel should have training in communication skills.

Reducing routine and intensive follow up is likely to release resources without compromising outcomes, allowing specialists to concentrate on patients who are more likely to benefit from their attention.

We acknowledge the assistance given by members of the Clinical Outcomes Group (COG) Cancer Subgroup, chaired by Professor Bob Haward, who commented on drafts of the Guidance for Purchasers from which this paper is derived. ${ }^{1}$ We also thank the review team at the Istituto di Richerche Farmacologthank "Mario Negri", Milan, and Dr Kay Dickersin of the Baltiiche "Mario Negri", Milan

1 Cancer Guidance Sub-Group of the Clinical Outcomes Group. Improving outcomes in breast cancer: guidance for purchasers; the manual. London: Department of Health 1996.

2 Cancer Guidance Sub-Group of the Clinical Outcomes Group. Improving outcomes in breast cancer: guidance for purchasers; the research evidence. London: Department of purchasers; the re.

3 Office of Populations, Censuses and Surveys. Mortality statistics, cause, 1993. London: HMSO, 1995. (Series DH2 No22.)

4 McCarthy $\mathrm{M}$, Bore J. Treatment of breast cancer in two teaching hospitals: a comparison with consensus guidelines. Eur $\mathcal{F}$ Cancer 1991;27:579-82.
5 Sainsbury R, Rider L, Smith A, MacAdam A. Does it matter where you live? Treatment variation for breast cancer in Yorkshire. Br f Cancer 1995;71:1275-8.

6 Sainsbury R, Haward B, Rider L, Johnston C, Round C. Influence of clinician workload and patterns of treatmen on survival from breast cancer. Lancet 1995;345:1265-70.

7 Gillis CR, Hole DJ. Survival outcome of care by specialist surgeons in breast cancer: a study of 3786 patients in the surgeons in breast cancer: a study of 3786
west of Scotland. BMF 1996;312:145-8.

8 Richards MA, Wolfe CDA, Tilling K, Barton J, Bourne HM, Gregory WM. Variations in management and survival of women under 50 years with breast cancer in the South Thames Region. Br F Cancer 1996;73:751-7.

9 Basnett I, Gill M, Tobias JS. Variations in breast cancer management between a teaching and a non-teaching district. Eur $\mathcal{f}$ Cancer 1992;28:1945-50.

10 Winstanley JHR, Leinster SJ, Wake PN, Copeland GP. The value of guidelines in a breast screening service. Eur $\mathcal{F}$ Surg Oncol 1995;21:140-2.

11 Baildam AD, Singleton J, Coyne J, Woodman CBJ. Primary breast care in premenopausal women: where do patients receive optimum treatment [abstract]? Eur $\mathcal{f}$ Surg Oncol 1995;21:437.

12 Schmidt WA, Wachtel MS, Jones MK, Thurmond AS, DuBois PM, Pommier RF, Vetto JT. The triple test: a costeffective diagnostic tool. Lab Med 1994;25:715-9.

13 Ciatto S, Cariaggi P, Bulgaresi P, Confortini M, Bonardi R. Fine needle aspiration cytology of the breast: review of 9533 consecutive cases. Breast 1993;2:87-90

14 Brown LA, Coghill SB, Powis SJA. Audit of diagnostic accuracy of FNA cytology specimens taken by the histopathologist in a symptomatic breast clinic. Cytopathology 1991;2:1-6.

15 Butler JA, Vargas HI, Worthen N, Wilson SE. Accuracy of combined clinical- mammographyc-cytologic diagnosis of dominant breast masses. Arch Surg 1990;12:893-6.

16 Cipolla C, Amato C, Di Lisi G, Graceffa G, Cassano T, Salanitro L, et al. Validita della tripletta: esame clinico mammografia e citologia per agoaspirazione nella diagnos del carcinoma delta mammella. Minerva Chir 1990 45:1375-8

17 Martelli G, Pilotti S, Coopmans de Yoldi G, Viganotti G Fariselli G, Lepera P, Moglia D. Diagnostic efficacy of physical examination, mammography, fine needle aspiration cytology (triple-test) in solid breast lumps: an analysi of 1708 consecutive cases. Tumori 1990;76:476-9.

18 Layfield LJ, Glasgow BJ, Cramer H. Fine-needle aspiration in the management of breast masses. Pathol Annu in the managem

19 Di Pietro S, Fariselli G, Bandieramonte G, Lepera P, Coopman de Yoldi G, Viganotti G, Pilotti S. Diagnostic efficacy of the clinical-radiological-cytological trial in solid breas lumps: results of a second prospective study on 631 patients. Eur $\mathcal{F}$ Surg Oncol 1987; 13:335-40.

20 Hermansen C, Skovgaard Poulsen H, Jensen J, Langfeldt B, Steenskov V, Frederiksen P, Myhre Jensen O. Diagnostic reability of combined physical examination, mammography, and fine-needle puncture ("triple-test") in breast phy, and fine-needle puncture

21 Di Pietro S, Fariselli G, Bandieramonte G, Coopmans de Yoldi G, Guzzon A, Viganotti G, Pilotti S. Systematic use of the clinical-mammographic-cytologic triplet for the early diagnosis of mammary carcinoma. Tumori 1985 71:179-85.

22 Dixon JM, Anderson TJ, Lamb J, Nixon SJ, Forrest APM Fine needle aspiration cytology in relationship to clinical examination and mammography in the diagnosis of a solid breast mass. Br f Surg 1984;71:593-6.

23 Azzarelli A, Guzzon A, Pilotti S, Quagliuolo V, Bono A, Di Pietro S. Accuracy of breast cancer diagnosis by physical radiologic and cytologic combined examinations. Tumor 1983;69:137-41

24 Hahn P, Hallberg O, Schnurer LB. Combination of clinical examination, mammography and aspiration cytology in the diagnosis of carcinoma of the breast (179 cases) Strahlentherapie 1980;156:475-9.

25 Thomas MJ, Fitzharris BM, Redding WH, Williams JE Trott PA, Powles TJ, et al. Clinical examination, Trott PA, Powles TJ, et al. Clinical examination, xeromammography, and fine-needle aspiration cyto
diagnosis of breast tumours. $B M \mathcal{F} 1978 ; 2: 1139-41$.

26 Kreuzer G, Boquoi E. Aspiration biopsy cytology, mammography and clinical exploration: a modern set up in diagnosis of tumors of the breast. Acta Oncol 1976;20:319 22.

27 Palombini L, Fulciniti F, Vetrani A, De Rosa G, Di Benedetto G, Zeppa P, Troncone G. Fine-needle aspiraBenedetto G, Zeppa P, Troncone $G$. Fine-needle aspiration biopsies of breast masses;a critical analysis of

28 Galea M, Blamey RW. Diagnosis by team work: an approach to conservatism. Br Med Bull 1991;47:295-304.

29 Green B, Dowley A, Turnbull LS, Smith PA, Leinster SJ, Winstanley JHR. Impact of fine-needle aspiration cytology, ultrasonography and mammography on open rate in patients with benign breast disease. Br $\mathcal{F}$ Surg 1995 82:1509-11.

30 Vetto J, Pommier R, Schmidt W, Wachtel M, DuBois P, Jones $M$, Thurmond A. Use of the "triple test" for palpable breast lesions yields high diagnostic accuracy and cost savings. Am f Surg 1995;169:519-22.

31 Kocjan G. Evaluation of the cost-effectiveness of establishing a fine needle aspiration cytology clinic in a hospital out-patient department. Cytopathology 1991;2:13-8. 
32 Koss LG. The palpable breast nodule: a cost-effectivenes analysis of alternate diagnostic approaches. Cancer 1993 72:1499-501.

33 Macmillan RD, Purushotham AD, George WD. Local recurrence following breast conserving surgery for breast cancer. Br f Surg 1996;83:149-55.

34 Early Breast Cancer Trialists' Collaborative Group. Effects of radiotherapy and surgery in early breast cancer. An overview of the randomised trials. $N$ Engl $f$ Med 1995;333:1444-55

35 Recht A, Houlihan MJ. Axillary lymph nodes and breast cancer: a review. Cancer 1995;76:1491-512.

36 Smitt MC, Nowels KW, Zdeblick MJ, Jeffrey S, Carlson RW, Stockdale FE, Goffinet DR. The importance of the lumpectomy surgical margin status in long term results of breast conservation. Cancer 1995;76:250-67.

37 Goldberg P, Stolzman M, Goldberg HM. Psychological considerations in breast reconstruction. Ann Plast Surg 1984;13:38-42.

38 Filiberti A, Tamburini M, Murru L, Lovo GF, Ventafridda V, Arioli N, Grisotti A. Psychologic effects and esthetic results of breast reconstruction after mastectomy. Tumori results of breast

39 O'Gormon EC, McCrum B. A comparison of the self-perceptions of women who have undergone mastectomy with those receiving breast reconstruction. Irish fournal of Psychiatric Medicine 1988;5:26-31.

40 Dean C, Chetty V, Forrest APM. Effects of immediate breast reconstruction on psychosocial morbidity after mastectomy. Lancet 1983; i:459-61.

41 Schain WS, Wellisch DK, Pasnau RO, Landsverk J. The sooner the better: a study of psychological factors in women undergoing immediate versus delayed breast reconstruction. Am $f$ Psychiatry 1985;142:40-6.

42 Stevens LA, McGrath MH, Druss RG, Kister SJ, Gump FE, Forde KA. The psychological impact of immediate breast reconstruction for women with early breast cancer. Plast Reconstr Surg 1984;73:619-28.

43 Cooper GG, Webster MHC, Bell G. The results of breast reconstruction following mastectomy. $\mathrm{Br} \mathcal{f}$ Plastic Surg 1984;37:369-72.

44 Mock V. Body image in women treated for breast cancer. Nurs Res 1993;42:153-7.

45 Schover LR, Yetman RJ, Tuason LJ, Meisler E, Esselstyn $\mathrm{CB}$, Hermann RE, et al. Partial mastectomy: the effects on psychosocial adjustment, body image and sexuality. Cancer 1995;75:54-64.

46 Noguchi M, Kitagawa H, Kinoshita K, Earashi M, Miyazaki I, Tatsukuchi S, et al. Psychologic and cosmetic selfassessments of breast conserving therapy compared with mastectomy and immediate breast reconstruction. F Surg Oncol 1993;54:260-6.

47 Wellisch DK, DiMatteo R, Silverstein M, Landsverk J, Hoffman R, Waisman J, et al. Psychological outcomes of breast cancer therapies: lumpectomy versus mastectomy. Psychosomatics 1989;30:365-73.

48 Pozo C, Carver CS, Noriega V, Harris SD, Robinson DS, Ketcham AS, et al. Effects of mastectomy versus lumpectomy on emotional adjustment to breast cancer: a prospective study of the first year postsurgery. $f$ Clin Oncol prospective study

49 Leinster SJ, Ashcroft JJ, Slade PD, Dewey ME. Mastectomy versus conservative surgery: psychological effects of the patient's choice of treatment. Fournal of Psychosocial Oncology 1989;7:179-92.

50 Levy SM, Herberman RB, Lee JK, Lippman ME, D'Angelo T. Breast conservation versus mastectomy: distress sequelae as a function of choice. $\mathcal{f}$ Clin Oncol 1989;7:367-75.

51 Early Breast Cancer Trialists' Collaborative Group. Effects of radiotherapy and surgery in early breast cancer. An overview of the randomised trials. $N$ Engl $f \mathrm{Med}$ 1995;333:1444-55.

52 Fisher B, Anderson S, Redmond CK, Wolmark N, Wickerham DL, Cronin WM. Reanalysis and results after 12 years of follow-up in a randomised clinical trial comparing total mastectomy with lumpectomy with or without intervention in the treatment of breast cancer. $N$ Engl $\mathcal{F}$ Med 1995;333:1456-61.

53 Liljegnen G, Holmberg L, Adami HO, et al. Sector resection with and without post operative radiotherapy for stage I breast cancer: five year results of a randomised trial. Upsalla-Orebro Breast Cancer Study Group. $¥$ Natl Cancer Inst 1994;86:717-22.

54 Cuzick J, Stewart H, Rutqvist L, Houghton J, Edwards R, Redmond C, et al. Cause-specific mortality in long-term Redmond C, et al. Cause-specific mortality in long-term survivors of breast cancer who participat

55 Mahrer Committee. Management of adverse effects following breast radiotherapy. London: Royal College of Radiologists, 1995

56 Bates T, Evans RGB. Report of the independent review commissioned by the Royal College of Radiologists into brachial plexus neuropathy after radiotherapy for breast carcinoma. London: The Royal College of Radiologists, 1995.

57 Early Breast Cancer Trialists' Collaborative Group. Systemic treatment of early breast cancer by hormonal, cytotoxic, or immune therapy. Lancet 1992;339:1-15;71-85.

58 Richard Grey: personal communication based on an update of the systematic review.

59 Bulbrook RD. Long term adjuvant therapy for primary breast cancer: more than five years of tamoxifen is no breast cancer: more than five years of
longer justified. $B M \mathcal{F}$ 1996;312:389-90.

60 Gelber RD, Cole BF, Goldhirsch A, Rose C, Fisher B, Osborne CK, et al. Adjuvant chemotherapy plus tamoxifen compared with tamoxifen alone for postmenopausal breast cancer: meta-analysis of quality-adjusted survival. Lance 1996;347:1066-70

61 Vickers AJ. Does acupuncture work? A systematic literature review of acupuncture anti-emesis as a test case. London: Research Council for Complementary Medicine, 1995.

62 The Australian and New Zealand Breast Cancer Trials Group, Clinical Oncological Society of Australia. A randomized trial in postmenopausal patients with advanced breast cancer comparing endocrine and cytotoxic therapy given sequentially or in combination. $f$ Clin Oncol given sequentially

63 Epstein R. Does the breast cancer dollar make sense? Eur $\mathcal{f}$ Cancer 1992;28:486-91.

64 Smith TJ, Hillner B. The efficacy and cost-effectiveness of adjuvant therapy of early breast cancer in pre-menopausal women. f Clin Oncol 1993;11:771-6.

65 Kattlove H, Liberati A, Keeler E, Brook RH. Benefits and costs of screening and treatment for early breast cancer. ҰAMA 1995;273:142-8.

66 Corry JF, Lonning PE. Systemic therapy in breast cancer: efficacy and cost-utility. Pharmaco-Economics 1994;5:198 212 .

67 National Cancer Alliance. "Patient-centred cancer services"? What patients say. The National Cancer Alliance, 1996.

68 Mosconi P, Meyerowitz BE, Liberati MC, Liberati A Disclosure of breast cancer diagnosis: patient and physician reports. GIVIO (Interdisciplinary Group for Cancer Care Evaluation, Italy). Ann Oncol 1991;2:273-80.

69 Lerman C, Daly M, Walsh WP, Resch N, Seay J, Barsevick $\mathrm{A}$, et al. Communication between patients with breast cancer and health care providers. Determinants and implications. Cancer 1993;72:2612-20.

70 Suominen T. Breast cancer patients' opportunities to participate in their care. Cancer Nurs 1992;15:68-72.

71 Amir M. Considerations guiding physicians when informing cancer patients. Soc Sci Med 1987;24:741-8.

72 Chaitchik S, Kreitler S, Shaked S, Schwartz I, Rosin R. Doctor-patient communication in a cancer ward. Cancer Education 1992;7:14-0.

73 Greenwald HP, Nevitt MC. Physician attitudes toward communication with cancer patients. Soc Sci Med 1982;16:591-0.

74 Griffiths $M$, Leek C. Patient education needs: opinions of oncology nurses and their patients. Oncol Nurs Forum 995;22:139-43.

75 Holland JC, Geary N, Marchini A, Tross S. An international survey of physician attitudes and practice in regard to revealing the diagnosis of cancer. Cancer Investigation 1987;5:151-0

76 Taylor KM. "Telling bad news": physicians and the disclosure of undesirable information. Sociology of Health and Illness 1988;10:109-31.

77 Siminoff LA, Fetting JH, Abeloff MD. Doctor-patient communication about breast cancer adjuvant therapy. $\mathcal{f}$ Clin Oncol 1989;7:1192-200

78 GIVIO. What doctors tell patients with breast cancer about diagnosis and treatment: finding from a study in genera hospitals. $\mathrm{Br} F$ Cancer 1986;54:319-26.

79 McHugh P, Lewis S, Ford S, Newland E, Rustin G, Coombes $\mathrm{C}$, et al. The efficacy of audiotapes in promoting psychological well-being in cancer patients: a randomised controlled trial. Br $₹$ Cancer 1995;74:388-92.

80 Dodd MJ. Efficacy of proactive information on self-care in radiation therapy patients. Heart Lung 1987;16:538-44.

81 Eardley A. Patients' worries about radiotherapy: evaluation of a preparatory booklet. Psychology and Health 1988;2:79 89.

82 Reynolds PM, Sanson-Fisher RW, Poole AD, Harker J, Byrne MJ. Cancer and communication: informationgiving in an oncology clinic. BMF 1981;ii:1449-0.

83 Deustch G. Improving communication with oncology patients: taping the consultation. Clin Oncol 1992;4:46-7.

84 Hogbin B, Fallowfield LJ. Getting it taped: the bad news consultation with cancer patients. $\mathrm{Br} f \mathcal{H}$ Hosp Med 1989;41:330.

85 Rainey LC. Effects of preparatory patient education for radiation oncology patients. Cancer 1985;56:1056-61.

86 Hack TF, Degner LF, Dyck DG. Relationship between preferences for decisional control and illness information among women with breast cancer: a quantitativ

87 Suominen $T$, Leino-Kilpi $H$, Laippala $P$. Breast cance patients' perceived participations in health care: how do patients themselves and nurses assess this participation? Nursing Ethics 1994;1:96-109.

88 Pierce PF. Deciding on breast cancer treatment: a description of decision behavior. Nurs Res 1993;42:22.

89 Degner LF, Sloan JA. Decision making during serious ilness: what role do patients really want to play? $\mathcal{f}$ Clin Epidemiol 1992;45:941-50.

90 Suominen T. Breast cancer patients' opportunities to participate in their care. Cancer Nurs 1992;15:68-72.

91 Siminoff LA, Fetting JH. Factors affecting treatment decisions for a life-threatening illness: the case of medical treatment of breast cancer. Soc Sci Med 1991;32:813-8.

92 Sutherland HJ, Llewellyn-Thomas HA, Lockwood, Tritchler DL, Till JE. Cancer patients: their desire for information and participation in treatment decisions. $f R$ Soc Med 1989;82:260-3.

93 Blanchard CG, Labrecque MS, Ruckdeschel JC, Blanchard E. Information and decision-making preferences of hospitalized adult cancer patients. Soc Sci Med 1988;27:1 139-0. 
94 Cassileth BR, Zupkis RV, Sutton-Smith K, March V. Information and participation preferences among cance patients. Ann Intern Med 1980;92:832-6.

95 Fallowfield LJ, Hall A, Maguire P, Baum M, A'Hern RP. A question of choice: results of a prospective 3-year follow-up study of women with breast cancer. Breast 1994 3:202-8.

96 Morris J, Royle GT. Offering patients a choice of surgery for early breast cancer: a reduction in anxiety and depression in patients and their husbands. Soc Sci Med 1988;26:583 5 .

97 Wilson RG, Hart A, Dawes PJ. Mastectomy or conservation the patient's choice. BMF 1988;297:1167-9.

98 Levy SM, Herberman RB, Lee JK, Lippman ME, D'Angelo T. Breast conservation versus mastectomy: distress sequelae as a function of choice. 7 Clin Oncol 1989;7:367-75.

99 Hughes KK. Psychosocial and functional status of breast cancer patients. The influence of diagnosis and treatment choice. Cancer Nurs 1993;16:222-9.

100 Pozo C, Carver CS, Noriega V, Harris SD, Robinson DS Ketcham AS, et al. Effects of mastectomy versus lumpectomy on emotional adjustment to breast cancer: a prospective study of the first year postsurgery. $\mathcal{F}$ Clin Oncol prospective study

101 Leinster SJ, Ashcroft JJ, Slade PD, Dewey ME. Mastectomy versus conservative surgery: psychological effects of the patient's choice of treatment. $\mathcal{f}$ Psychosoc Oncol 1989;7:179-92.

102 Wolberg WH, Tanner MA, Romsaas EP, Trump DI Malec JF. Factors influencing options in primary breast cancer treatment. 7 Clin Oncol 1987;5:68-74.

103 Cotton T, Locker AP, Jackson L, Blamey RW, Morgan DA A prospective study of patient choice in treatment for primary breast cancer. Eur 7 Surg Oncol 1991;17:115-7.

104 Ward S, Heidrich S, Wolberg W. Factors women take into account when deciding upon type of surgery for breast cancer. Cancer Nurs 1989;12:344-51.

105 Street RL, Voigt B, Geyer C, Manning T, Swanson GP. Increasing patient involvement in choosing treatment for early breast cancer. Cancer 1995;76:2275-85

106 Ford S. Can oncologists detect distress in their outpatients and how satisfied are they with their performance during bad news consultations? Br $\mathcal{F}$ Cancer 1994;70:767-70.

107 Wilkinson S. Factors which influence how nurses communicate with cancer patients. F Adv Nurs 1991;16:677-88.

108 Maguire P, Tait A, Brooke M, Thomas C, Sellwood R. The effects of counselling on the psychiatric morbidity associated with mastectomy. BMF 1980;281:1454-6.

109 Ramirez AJ. Liaison psychiatry in a breast cancer unit. $f R$ Soc Med 1989;82:15-7.

110 Silberfarb PM, Maurer LH, Crouthamel CS. Psychosocial aspects of neoplastic disease: 1 . Functional status of breast cancer patients during different treatment regimens. $A m \mathcal{F}$ Psychiatry 1980;137:450.

111 Spiegel D, Kraemer HC, Bloom JR, Gottheil E. Effect of psychosocial treatment on survival of patients with psychosocial treatment on survival of patient

112 McArdle JMC, George WD, McArdle CS, Smith DC Moodie AR, Hughson AVM, Murray GD. Psychological support for patients undergoing breast cancer surgery: a randomised study. $B M \mathcal{F} 1996 \cdot 312 \cdot 813-7$.

113 Burton MV, Parker RW, Farrell A, Bailey D, Connelly Booth S, Elcombe S. A randomized controlled trial of preoperative psychological preparation for mastectomy. Psycho-oncology 1995;4:1-19.

114 Edgar L, Rosberg Z, Nowlis D. Coping with cancer during the first year after diagnosis. Cancer 1992;69:817-28.

115 Spiegel D, Bloom JR. Group therapy and hypnosis reduce metastatic breast carcinoma pain. Psychosom Med 1983; 45:333-9.

116 Spiegel D, Bloom JR, Yalom I. Group support for patients with metastatic cancer. A randomized outcome study. Arch Gen Psychiatry 1981;38:527-33.

117 Watson M, Denton S, Baum M, Greer S. Counselling breast cancer patients: a specialist nurse service. Counselling Psychiatry Quarterly 1988;1:25-34.

118 Mock V, Burke MB, Sheehan P, Creaton EM, Winning ham ML, McKennedy-Tedder S, et al. A nursing rehabilitation program for women with breast cancer receiving adjuvant chemotherapy. Oncol Nurs Forum 1994;21:899907.

119 Grossarth MR, Eysenck HJ. Length of survival and lymphocyte percentage in women with mammary cance as a function of psychotherapy. Psych Rep 1989;65:315-24

120 Telch CF, Telch MJ. Group coping skills introduction and supportive group therapy for cancer patients: a comparison of strategies. $\mathcal{F}$ Consult Clin Psychol 1986;54:802-8.

121 Maguire P, Brooke M, Tait A, Thomas C, Sellwood R. The effect of counselling on physical disability and social recovery after mastectomy. Clin Oncol 1983;9:319-24.

122 Gordon WA, Freidenbergs I, Diller L, Hibbard M, Wolf C, Levine $\mathrm{L}$, Lipkins RE. Efficacy of psychological interven-
tion with cancer patients. $\mathcal{F}$ Consult Clin Psychol 1980; 48:743-59.

123 Houts PS, Whitney CW, Mortel R, Bartholomew MJ Former cancer patients as counsellors of newly diagnosed cancer patients. $\mathcal{F}$ Natl Cancer Inst 1986;76:793-6.

124 Youssef FA. Crisis intervention: a group therapy approach for hospitalized breast cancer patients. $\mathcal{f} A d v$ Nurs 1984;9:307-13

125 Morgenstern H, Gellert GA, Walter SD, Ostfeld AM, Siegel BS. The impact of a psychosocial support program on survival with breast cancer: the importance of selection bias in program evaluation. $\mathcal{F}$ Chron Dis $1984 ; 37: 273-82$.
126 Mayer TJ, Mark MM. Effects of psychosocial interventions with adult cancer patients: a meta-analysis of randomised experiments. Health Psychol 1995;14:101-8.

127 Fawzy FI, Fawzy NW, Arndt LA, Pasnau RO. Critical review of psychosocial interventions in cancer care. Arch Gen Psychiatry 1995;52:100-13.

128 Moorey S, Greer S, Watson M, Baruch JDR, Robertson $\mathrm{BM}$, Mason A, et al. Adjuvant psychological therapy for patients with cancer: outcome at one year. Psycho-oncology 1994;3:39-46

129 Bindemann S, Soukop M, Kaye SB. Randomised controlled study of relaxation training. Eur f Cancer 1991;27:1704.

130 Bridge LR, Benson P, Pietroni RC, Priest RG. Relaxation and imagery in the treatment of breast cancer. BMF 1988; 297:1169-72.

131 Morrow GR, Asbury R, Hammon S, Dobkin P, Caruso J, Pandja K, Rosenthal S. Comparing the effectiveness of behavioral treatment for chemotherapy-induced nausea and vomiting when administered by oncologists, oncolog nurses, and clinical psychologists. Health Psychol 1992 11:250-6.

132 Morrow GR, Morrell C. Behavioral treatment for the anticipatory nausea and vomiting induced by cancer chemotherapy. N Engl f Med 1982;307:1476-80.

133 Burish TG, Snyder SL, Jenkins RA. Preparing patients for cancer chemotherapy: effects of coping preparation and relaxation interventions. F Consult Clin Psychol 1991; 59:518-25.

134 Lyles JN, Burish TG, Krozely MG, Oldham RK. Efficacy of relaxation training and guided imagery in reducing the aversiveness of cancer chemotherapy. $\mathcal{F}$ Consult Clin Psycho 1982;50:509-24.

135 Dalton JA. Education for pain management: a pilot study. Patient Education and Counselling 1987;9:155-65.

136 Arathuzik D. Effects of cognitive-behavioral strategies on pain in cancer patients. Cancer Nurs 1994;17:207-14.

137 Gruber BL, Hersh SP, Hall NR, Waletzky LR, Kunz JF, Carpenter JK, et al. Immunological responses of breast cancer patients to behavioural interventions. Biofeedback Self Regul 1993;18:1-22.

138 Davis $\mathrm{H}$. Effects of biofeedback and cognitive therapy on stress in patients with breast cancer. Psychol Rep 1986; 59:967-74.

139 Berglund G, Bolund C, Gustafsson U, Sjoden P. A randomised study of a rehabilitation program for cancer patients: the starting again group. Psycho-oncology 1994; 3:109-20.

140 Greer S, Moorey S, Baruch J. Adjuvant psychological therapy for patients with cancer: a prospective randomised trial. $B M F$ f 1992;304:675-80

141 Cimprich B. Development of an intervention to restore attention in cancer patients. Cancer Nurs 1993;76:83-92.

142 Cannici J, Malcolm R, Peek LA. Treatment of insomnia in cancer patients using muscle relaxation training. 7 Behav Ther Exp Psychiatry 1983;14:251-6.

143 Burish TG, Lyles JN. Effectiveness of relaxation training in reducing adverse reactions to cancer chemotherapy. $f$ Behav Med 1981;4:65-78.

144 Norcross Weinstreub F, Hagopian GA. The effect of nursing consultation on anxiety, side effects, and self-care of patients receiving radiation therapy. Oncol Nurs Forum 1990;(suppl 17):31-8.

145 Larsson G, Starrin B. Relaxation training as an integral part of caring activities for cancer patients: effects on wellbeing. Scand f Caring Sci 1992;6:179-85.

146 Burish TG, Jenkins RA. Effectiveness of biofeedback and relaxation training in reducing the side-effects of cancer chemotherapy. Health Psychol 1992;11:65-78.

147 Cotanch PE, Strum S. Progressive muscle relaxation as antiemetic therapy for cancer patients. Oncol Nurs Forum 1987;14:33-7.

148 Burish TG, Carey MP, Krozely MG, Greco FA. Conditioned side effects induced by cancer chemotherapy: prevention through behavioral treatment. $\mathcal{f}$ Consult Clin Psychol 1987;55:42-8.

149 McLean M. Stress reduction with radiotherapy breast patients. Radiography Today 1989;55:11-3.

150 Maunsell E, Brisson J, Deschenes L. Social support and survival among women with breast cancer. Cancer 1995;76:631-7.

151 Roberts CS, Cox CE, Shannon VJ, Wells NL. A closer look at social support as a moderator of stress in breast cancer. Health Soc Work 1994;19:157-64.

152 Waxler-Morrison N, Hislop TG, Mears B, Kan L. Effects of social relationships on survival for women with breast cancer: a prospective study. Soc Sci Med 1991;33:177-83.

153 Zemore R, Shepel LF. Effects of breast cancer and mastectomy on emotional support and adjustment. Soc Sci Med 1989;28:19-27.

154 Neuling SJ, Winefield HR. Social support and recovery after surgery for breast cancer: frequency and correlates of supportive behaviours by family, friends and surgeon. Soc Sci Med 1988;27:385-92.

155 Northouse LL. Social support in patients' and husbands' adjustment to breast cancer. Nurs Res 1988;37:91-5.

156 Bloom J, Spiegel D. The relationship of two dimensions of social support to the psychological well-being and social functioning of women with advanced breast cancer. $S o c S c i$ Med 1984;19:831-7.

157 Funch DP, Mettlin C. The role of support in relation to recovery from breast surgery. Soc Sci Med 1982;16:91-8. 
158 Vachon ML, Lyall WA, Rogers J, Cochrane J, Freeman SJ. The effectiveness of psychosocial support during postsurgical treatment of breast cancer. Int 7 Psychiatry Med $1981 ; 4: 365-71$.

159 Grunfeld E, Mant D, Vessey MP, Yudkin P. Evaluating primary care follow-up of breast cancer: methods and preliminary results of three studies. Ann Oncol 1995; 6:S47-52.

160 The GIVIO Investigators. Impact of follow-up testing on survival and health-related quality of life in breast cancer patients. A multicentre randomised controlled trial. $7 A M A$ 1994;271:1587-92

161 Rosselli Del Turco M, Palli D, Cariddi A, Ciatto S, Pacin $P$, Distante $V$. Intensive diagnostic follow-up after treatment of primary breast cancer. A randomised trial ҰAMA 1994;271:1593-7.

162 Grunfeld E, Mant D, Yudkin P, Adewuyi-Dalton R, Cole $\mathrm{D}$, Stewart J, et al. Routine follow up of breast cancer in primary care: randomised trial. BMF 1996;313:665-9.

163 Mapelli V, Dirindin N, Grilli R. Economic evaluation of diagnostic follow-up after primary treatment for breast diagnostic follow-up after prima
cancer. Ann Oncol 1995;6:S61-4.

164 Schapira V, Urban N. A minimalist policy for breast cancer surveillance. FAMA 1991;265:380-2.

165 Simon MS, Stano M, Hussein M, Hoff M, Smith D. An analysis of the cost of clinical surveillance after primary therapy for women with early stage invasive breast cancer Breast Cancer Res Treat 1996;37:39-47.

166 Nattinger AB, Gottlieb MS, Veum J, Yahnke D, Goodwin JS. Geographic variation in the use of breast conserving treatment for breast cancer. N Engl F Med 1992;326:11027 .

167 Lee-Feldstein A, Anton-Culver H, Feldstein PJ. Treatment differences and other prognostic factors related to breast differences and other prognostic factors related to breast
cancer survival. Delivery stems and medical outcomes. cancer survival. Deliver

168 Satariano ER, Swanson GM, Moll PP. Non-clinical factors associated with surgery received for treatment of earlystage breast cancer. Am f Public Health 1992;82:195-8.

169 Hynes DM. The quality of breast cancer care in local communities: implications for health care reforms. Med Car 1994;32:328-40.

170 Scorpiglione N, Nicolucci A, Grilli R, et al. Appropriateness and variation of surgical treatment of breast cancer in Italy: when excellence in clinical research does not match with generalized quality of care. $f$ Clin Epidemiol with generalized

171 Grilli R, Mainini F, Penna A, et al. Inappropriate Halsted mastectomy and patient volume in Italian hospitals. $A m$. Public Health 1993;83:1762-4.

172 Samet JM, Hunt WC, Farrow DC. Determinants of receiving breast conserving surgery. The surveillance, epidemiology, and end results program, 1983-6. Cancer 1994 73:2344-51.

173 GIVIO (Interdisciplinary Group for Cancer Care Evaluation). Diagnosis and first-line treatment of breast cancer in Italian general hospitals. Timori 1986;72:273-83.

174 Foster RS, Farwell ME, Costanza MC. Breast-conserving surgery for breast cancer: patterns of care in a geographic region and estimation of potential applicability. Ann Surg region and estimation

175 Studnicki J, Shapira DV, Bradham DD, Clark RA, Jarrett A. Response to the National Cancer Institute Alert. The effect of practice guidelines on two hospitals in the same medical community. Cancer 1993;72:2986-92.

176 Hand R, Sener S, Imperato J, Chmiel JS, Sylvester J, Fremgen A. Hospital variables associated with quality of care for breast cancer patients. $¥ A M A$ 1991;266:3429-32.

177 Byrne MJ, Jamrozik K, Parsons RW, et al. Breast cancer in Western Australia. Diagnosis and primary treatment. Aust NZ F Surg 1993;63:624-9.

178 Boffetta P, Merletti F, Winkelmann R, Magnani C, Cappa APM, Terracini B. Survival of breast cancer patients from Piedmont, Italy. Cancer Causes Control 1993;4:209-15.

179 Sloan FA, Perrin JM, Valvona J. In-hospital mortality of surgical patients: is there an empiric basis for standard setting? Surgery 1986;99:446-53.
180 Hill DJ, White VM, Giles GG, Collins JP, Kitchen PRB. Changes in the investigation and management of primary operable breast cancer in Victoria. Med F Aust 1994; 161:110-22.

181 Miransky J, Kerner JF, Sturgeon SR, et al. A comparison of primary breast cancer management in small, intermediate and large community hospitals and a comprehensive cancer center. In: Engstrom PF, Anderson PN, Mortenson cer center. In: Engstrom PF, Anderson PN, Mortenson
$\mathrm{LE}$, eds. Advances in cancer control: epidemiology and research. New York: Liss AR, 1984:87-96.

182 Ferguson CM, Feinstein AC, Pendergrast WJ. Determinants of primary therapy of early stage breast cancer. $F$ Med Assoc Ga 1990;79:351-4.

183 Stiller CA. Centralised treatment, entry to trials and survival. Br f Cancer 1994;70:352-62.

184 Neufeld KR, Degner LF, Dick JAM. A nursing intervention strategy to foster patients involvement in treatment decisions. Oncol Nurs Forum 1993;20:631-5.

185 Suominen T. How do nurses assess the information received by breast cancer patients? f Adv Nurs 1993;18:64

186 Suominen T, Laippala P. Breast cancer patients. The support given by nurses. Scandinavian fournal of the Carin Sciences 1993;7:131-4.

187 Alexander MA. Evaluation of a training program in breast cancer nursing. Fournal of Continuing Education in Nursing 1991;21:260-5

188 Vorcross Weinstreub F, Hagiopian GA. The effect of nursing consultation on anxiety, side effects, and self-care of patients receiving radiation therapy. Oncol Nurs Forum 1990;(suppl 17):31-8.

189 Roberts R, Fallowfield L. Who supports the cancer counsellors? Nursing Times 1990;36:32-4

190 Watson M, Denton S, Baum M, Greer S. Counselling breast cancer patients: a specialist nurse service. Coumselling Psychiatry Quarterly 1988;1:25-34.

191 Faulkner A, Maguire P. Teaching ward nurses to monitor cancer patients. Clin Oncol 1984;10:383-9.

192 Ray C, Grover J, Wisniewski T Nurses' perceptions of early breast cancer and mastectomy, and their psychological implications, and of the role of health professionals in providing support. Int $\mathcal{f}$ Nurs Stud 1984;21:101-11.

193 Whelan J Oncology nurses' attitude towards cancer treatment and survival. Cancer Nurs 1984;7:375-84.

194 Youssef FA. Crisis intervention: a group-therapy approach for hospitalized breast cancer patients. I Adr Nius 1984;9:307-13

195 Hansen JL. Assessing the mastectomy patient's need for special coping strategies. F Pract Nurs 1983;33:24.

196 Maguire P, Brooke M, Tait A, Thomas C, Sellwood R. The effect of counselling on physical disability and social recovery after mastectomy. Clin Oncol 1983;9:319-24.

197 Maguire P, Pentol A, Allen D, Tait A, Brooke M, Sellwood $\mathrm{R}$. Cost of counselling women who undergo a mastectomy: BMF 1980;281:1454-6.

198 Tait A, Maguire P, Faulkner A, et al. Improving communications skills. Standardised assessments may help nurses to detect psychiatric problems as they develop in mastectom patients. Nursing Times 1982;78:2181-4.

199 Bullough B. Nurses as teachers and support persons for breast cancer patients. Cancer Nurs 1981;4:221-5.

200 Maguire P, Tait A, Brooke M, Thomas C, Sellwood R. The effects of counselling on the psychiatric morbidity associated with mastectomy. BMf 1980;281:1454-6.

201 Porter HB. The effect of ambulatory oncology nursin practice models on health resource utilization. Part 1 . Collaboration or compliance? $\mathcal{F}$ Nurs Admin 1995;25:21-9.

202 Porter HB. The effects of ambulatory oncology nursing practice models on health resource utilization. Part 2. Different practice models - different use of health resources? $\mathscr{F}$ Nurs Admin 1995;25:15-24.

203 NHS Centre for Reviews and Dissemination, University of York, and Nuffield Institute for Health, University of Leeds. Implementing clinical practice guidelines: can guidelines be used to improve clinical practice? Effectic Health Care 1996;1:8. 